\title{
Potent and Highly Selective Hypoxia-Activated Achiral Phosphoramidate Mustards as Anticancer Drugs
}

\author{
Jian-Xin Duan, ${ }^{*}, \dagger$ Hailong Jiao, ${ }^{\dagger}$ Jacob Kaizerman, ${ }^{\dagger}$ Timothy Stanton, ${ }^{\dagger}$ James W. Evans, ${ }^{\dagger}$ Leslie Lan $^{\dagger}$ Gustavo Lorente $^{\dagger}$ \\ Monica Banica ${ }^{\dagger}$ Don Jung, ${ }^{\dagger}$ Jinwei Wang, ${ }^{\ddagger}$ Huaiyu Ma, ${ }^{\ddagger}$ Xiaoming Li,${ }^{\ddagger}$ Zhijian Yang, ${ }^{\ddagger}$ Robert M. Hoffman, ${ }^{\ddagger}$ \\ W. Steve Ammons, ${ }^{\dagger}$ Charles P. Hart, ${ }^{\dagger}$ and Mark Matteucci* ${ }^{\dagger}$ \\ Threshold Pharmaceuticals, 1300 Seaport Boulevard, Suite 500, Redwood City, California 94063, and AntiCancer, Inc., 7917 Ostrow Street, \\ San Diego, California 92111
}

Received August 17, 2007

\begin{abstract}
A series of achiral hypoxia-activated prodrugs were synthesized on the basis of the DNA cross-linking toxin of the prodrug, ifosfamide. The hypoxia-selective cytotoxicity of several of the compounds was improved over previously reported racemic mixtures of chiral bioreductive phosphoramidate prodrugs. Prodrugs activated by 2-nitroimidazole reduction demonstrated up to 400 -fold enhanced cytotoxicity toward H460 cells in culture under hypoxia versus their potency under aerobic conditions. Compounds were further assessed for their stability to cytochrome P450 metabolism using a liver microsome assay. The 2-nitroimidazole containing lead compound $\mathbf{3 b}$ (TH-302) was selectively potent under hypoxia and stable to liver microsomes. It was active in an in vivo MIA PaCa-2 pancreatic cancer orthotopic xenograft model as a monotherapy and demonstrated dramatic efficacy when used in combination with gemcitabine, extending survival with one of eight animals tumor free at day-44. Compound $\mathbf{3 b}$ has emerged as a promising antitumor agent that shows excellent in vivo efficacy and is currently being evaluated in the clinic.
\end{abstract}

\section{Introduction}

Hypoxia within the tumor microenvironment confers resistance to radiation and chemotherapy. The inability to treat the hypoxic compartment of tumors represents a critical unmet medical need and an opportunity for the development of novel therapeutics that selectively target hypoxic tumor cells. ${ }^{1-7}$ Efforts toward prodrugs, which are selectively activated within a hypoxic compartment, started with simple nitrobenzyl systems over 25 years ago. ${ }^{8}$

The hypoxia-activated prodrug that is clinically most advanced is tirapazamine, and it has been tested in phase- 3 clinical trials for treating a variety of different solid tumor malignancies. ${ }^{9,10}$ Tirapazamine, however, suffers from several deficiencies, most notably, poor tumor penetration ${ }^{11-13}$ and low in vivo potency at tolerated doses. ${ }^{14}$ Improved hypoxia-activated prodrugs are clearly of interest with two others, banoxantrone (AQ4N) ${ }^{15}$ (see Figure 1) and 2-[(2-bromoethyl)-2,4-dinitro-6-[[[2-phosphonooxyl]ethyl]amino]carbonyl]aniline]-ethyl methanesulfonate (PR104), ${ }^{16}$ currently undergoing early clinical testing.

Hypoxia-activated phosphoramidate DNA cross-linking mustards were introduced by Borch and co-workers. ${ }^{17,18}$ The most successful were 5-nitrothiophene- and 5-nitrofuran-triggered prodrugs of phosphoramidate toxins. This toxin class was based on cyclophosphamide (Figure 1), a commonly used antitumor agent. ${ }^{19}$ In a clonogenic assay with HT-29 cells, the lead compound from this series is active under hypoxic conditions $\left(\mathrm{LC}_{99}{ }^{a}=0.22 \mu \mathrm{M}\right)$ but showed only a low hypoxia selectivity of 8.2-fold compared to its normoxic cytotoxicity. We sought to re-explore the hypoxia-activated phosphoramidate bis alkylator prodrug area with the goal of increasing the selectivity of

* To whom correspondence should be addressed. Telephone: $650-474-$ 8231. Fax: 650-474-0408. E-mail: jduan@ thresholdpharm.com (J.-X.D.); Telephone: 650-474-8225. Fax: 650-474-0408. E-mail: mmatteucci@ thresholdpharm.com (M.M).

$\dagger$ Threshold Pharmaceuticals.

* AntiCancer, Inc. the prodrugs for hypoxic cells and improving the therapeutic index. We also sought to eliminate the chirality at the phosphorus atom to avoid the problem of a racemic mixture. Here, we report our effort on the structure-activity relationship (SAR) of prodrugs around the symmetric phosphoramidate toxin derived from the antitumor prodrug ifosfamide (Figure 1). ${ }^{20}$ This effort has resulted in the identification of a highly selective potent achiral candidate with excellent in vivo efficacy.

Isophosphoramide mustard (IPM, 1a, Figure 1) is the cytotoxin generated from the cytochrome P450 activation of the clinically useful prodrug, ifosfamide. Its proven efficacy in the clinic and the opportunity to synthesize achiral prodrugs define it as a useful toxin for prodrug efforts. ${ }^{20}$

2-Nitroimidazoles undergo hypoxia-selective biochemical reduction in both cellular and in vivo systems. 2-Nitroimidazoles, such as Pimonidazole ${ }^{21}$ and EF5 ${ }^{22}$ have been widely used to selectively label the hypoxic zone of tumors immunohistochemically. ${ }^{18} \mathrm{~F}$-based 2 -nitroimidazole probes, such as ${ }^{18} \mathrm{~F}$ misonidazole (FMISO) and ${ }^{18} \mathrm{~F}$-fluoroazamycin (FAZA) ${ }^{23}$ (Figure 2), are being developed as positron emission tomography (PET) probes for preclinical and clinical hypoxia imaging.

The 2-nitroimidazol-5-yl methyl system has been used to release amine-bearing drugs via a carbamate linkage in cell culture. $^{24-26}$ We investigated whether 2-nitroimidazole would serve as a hypoxic trigger for achiral phosphoramidate prodrugs. Compound 3a was selected as a target compound, using 2-nitroimidazole as the hypoxic trigger and IPM as the released toxin.

\section{Chemistry}

The synthesis of 2-nitroimidazole phosphoramidate conjugates has not been reported in the literature. Initial attempts to

\footnotetext{
${ }^{a}$ Abbreviations: DIAD, diisopropyl azodicarboxylate; DCM, dichloromethane; FMISO, ${ }^{18} \mathrm{~F}$-misonidazole; FAZA, ${ }^{18} \mathrm{~F}$-fluoroazamycin; HCR, hypoxic cytotoxicity ratio; $\mathrm{IC}_{50}$, half-maximal inhibitory concentration; $\mathrm{LC}_{99}$, concentration that reduces clonogenic survival by $2 \log$ units; IPM, isophosphoramide mustard; MTD, maximum tolerated dose.
} 
<smiles>O=P(O)(NCCCl)NCCCl</smiles>

IPM, 1a<smiles>O=P1(NCCCl)OCCCN1CCCl</smiles>

ifosfamide<smiles>NP(=O)(O)N(CCCl)CCCl</smiles>

cyclophosphamide mustard<smiles>O=P1(N(CCCl)CCCl)NCCCO1</smiles>

cyclophosphamide<smiles>C[N+](C)(C)CCNc1ccc(NCC[N+](C)(C)[O-])c2c1C(=O)c1c(O)ccc(O)c1C2=O</smiles>

banoxantrone

Figure 1. Chemical structures of ifosfamide mustard (IPM), ifosfamide, cyclophosphamide mustard, cyclophosphamide, and banozantrone.<smiles>O=[N+]([O-])c1nccn1CC(O)CN1CCCCC1</smiles>

Pimonidazole<smiles>O=C(Cn1ccnc1[N+](=O)[O-])NCC(F)(F)C(F)(F)F</smiles>

EF5<smiles>O=[N+]([O-])c1nccn1CC(O)C[18F]</smiles>

${ }^{18} \mathrm{~F}$-FMISO<smiles>O=[N+]([O-])c1nccn1[C@@H]1OC(C[18F])[C@@H](O)[C@H]1O</smiles>

${ }^{18}$ F-FAZA

Figure 2. Chemical structures of Pimonidazole, EF5, ${ }^{18} \mathrm{~F}-\mathrm{FMISO}$, and ${ }^{18} \mathrm{~F}-\mathrm{FAZA}$.

Scheme $\mathbf{1}^{a}$<smiles>Cn1c(CO)cnc1[N+](=O)[O-]</smiles>

${ }^{a}$ Reagents and conditions: (a) $\mathrm{TMS}_{2} \mathrm{NLi},-78{ }^{\circ} \mathrm{C}$; (b) $\mathrm{PCl}_{3}$; (c) $\mathrm{NH}_{2} \mathrm{CH}_{2} \mathrm{CH}_{2} \mathrm{Cl} \cdot \mathrm{HCl}$; (d) meta-chloroperoxybenzoic acid.

synthesize them following the published synthetic method for nitrofuranyl derivatives of the related phosphoramidate toxin derived from cyclophosphamide ${ }^{17}$ resulted in the formation of only 1-methyl-2-nitro-5-chloromethylimidazole (Scheme 1).

Compound 3a was successfully synthesized in $80 \%$ yield by a Mitsunobu reaction as shown below in Scheme 2. The bromo analogue, $\mathbf{3 b}$, and other nitroazole-containing prodrugs were synthesized under similar conditions.

Hypoxia-activated prodrugs containing $N, N$-dialkyl phosphoramidate mustards were synthesized as shown in Scheme 3. ${ }^{17,18}$ $\mathrm{POCl}_{3}$ was reacted with 1 equiv of $\mathrm{N}$-methyl-chloroethylamine, and the resulted monoamidate was purified by distillation. The addition of the second $\mathrm{N}$-methyl-chloroethylamine was followed by purification of the bis amidate via flash chromatography. The final addition of $\mathbf{2}$ to produce $\mathbf{4 a}$ was accomplished under basic conditions. Compound $\mathbf{4 b}$ was synthesized via a one-pot procedure with the sequential addition of 2 equiv of bis chloroethylamine followed by $\mathbf{2}$ and oxidation.

Compound 6, the lead compound from Borch et al.'s series, was synthesized on the basis of the literature method ${ }^{17}$ (Scheme 4).

\section{Results and Discussion}

In vitro cytotoxicity: The compounds were evaluated for cytotoxicity under normoxic (air atmosphere) and hypoxic $\left(\mathrm{N}_{2}\right.$ atmosphere) conditions using the H460 human non-small-cell lung cancer cell line. This cell line provides a stringent test for hypoxic/normoxic selectivity because it is known to express high levels of DT diaphorase, ${ }^{27}$ an oxygen-insensitive 2-electron
Scheme $2^{a}$<smiles>[X]CCNP(=O)(O)NCC[X]</smiles><smiles>[R]O[NH2+]P(=O)(NCCBr)NCCBr</smiles><smiles>[R]O[N+](=O)c1ccc(CO)o1</smiles><smiles>O=[N+]([O-])c1ccc(CO)s1</smiles>

${ }^{a}$ Reagents and conditions: (a) $\mathrm{PPh}_{3}$, DIAD, THF, $0{ }^{\circ} \mathrm{C}$ to room temperature.

reductase. This broadly-expressed enzyme ${ }^{28}$ has the potential to activate these prodrugs through a non-hypoxic activation pathway, thereby increasing the toxicity of the prodrugs under normoxic conditions. Cells were treated with test compounds at various concentrations under air or $\mathrm{N}_{2}$ for $2 \mathrm{~h}$, washed, and incubated in air for 3 days in fresh medium. Cell viability and proliferation were then assessed by Alamar Blue staining. The $\mathrm{IC}_{50}$ values for the inhibition of proliferation for the tested compounds are shown in Table 1.

The in vitro activity of the first prodrug of the series, 3a, confirmed our interest in 2-nitroimidazole phosphoramidate prodrugs by demonstrating a very high hypoxic selectivity (HCR $=420$ ). Substitution of the chlorine with bromine on the phosphorus mustard in $\mathbf{3 b}$ increased the potency by 10 -fold and 
Scheme $3^{a}$
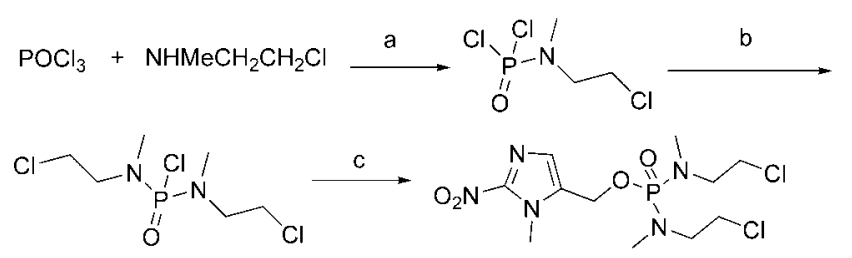

$4 a$

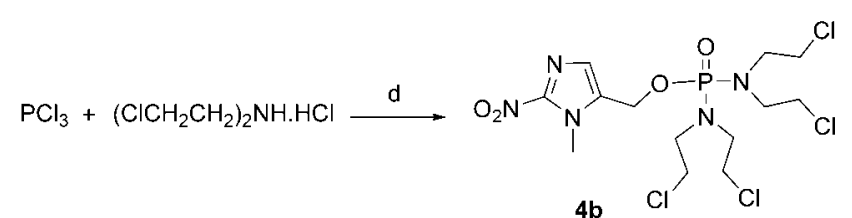

${ }^{a}$ Reagents and conditions: (a) reflux; (b) $\mathrm{NHMeCH}_{2} \mathrm{CH}_{2} \mathrm{Cl}$, DIEA; (c) 2, $\mathrm{TMS}_{2} \mathrm{NLi}$; (d) TEA, DCM, room temperature; then 2 in DCM; and then tert-butyl hydroperoxide, $-20{ }^{\circ} \mathrm{C}$ to room temperature.

\section{Scheme $4^{a}$}

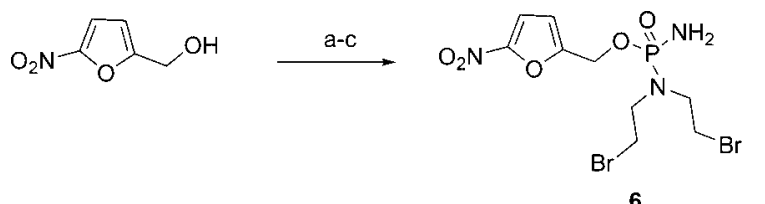

${ }^{a}$ Reagents and conditions: (a) $\mathrm{TMS}_{2} \mathrm{NLi},-78{ }^{\circ} \mathrm{C}$; (b) $\mathrm{POCl}_{2} \mathrm{~N}\left(\mathrm{CH}_{2}-\right.$ $\left.\mathrm{CH}_{2} \mathrm{Br}\right)_{2}$; (c) $\mathrm{NH}_{3}$.

maintained the high hypoxic selectivity $(\mathrm{HCR}=270)$. Symmetric alkyl substitutions on the phosphoramidate nitrogens and their effect on potency and hypoxic selectivity were of interest. Specifically, we synthesized the methyl- and chloroethylsubstituted analogues. $\gamma$-Glutamyl- $\alpha$-amino- $\beta$-[[[2-[[bis[bis $(2-$ chloroethyl)amino]phosphoryl]oxy]ethyl]sulfonyl]-propionyl]$(R)-(-)$-phenylglycine (TLK286), ${ }^{29}$ the glutathione-transferaseactivated phosphoramidate prodrug, uses the latter tetrakis chloroethyl phosphoramidate toxin. The substitution of alkyl groups on the phosphoramidate nitrogens slightly increased the potency of the prodrugs, $\mathbf{4 a}$ and $\mathbf{4 b}$, under hypoxic conditions but slightly decreased the hypoxic selectivity, particularly, in the case of $\mathbf{4 a}$.

The 2-nitroimidazole confers striking hypoxic/normoxic selectivity to the prodrug constructs both in the case of $\mathbf{3 a}$ and 3b. The isomeric 5-nitroimidazole-containing analogue, $\mathbf{5 b}$, results in lower potency under hypoxic conditions and less selectivity. This is consistent with previously reported phosphoramidate work ${ }^{17}$ and is likely the result of the difficulty of mammalian reductases to reduce 5-nitroimidazoles because of the lower reduction potential of 5-nitroimidazole compared to 2-nitroimidazole. ${ }^{30}$ The single-electron reduction potential for corresponding methanols has been reported to be $-421 \mathrm{mV}$ for $\mathrm{N}$-methyl-2-nitroimidazole methanol and $-483 \mathrm{mV}$ for $\mathrm{N}$-methyl-5-nitroimidazole methanol. ${ }^{30}$ The 5-nitrofuran derivative, 5a, also demonstrates good hypoxic selectivity $(\mathrm{HCR}=170)$. This selectivity is unprecedented for the nitrofuranyl system. The symmetric prodrug 5a shows 3-fold greater selectivity than the racemic isomer $\mathbf{6}$, reported by Borch. ${ }^{17}$

Clonogenic Survival Cytotoxicity Assays. Compounds 3b and 5a were further characterized using an in vitro clonogenic survival assay with human lung cancer H460 cells and human colon cancer HT29 cells. The results for both cell lines are shown in Figures 3 and 4 and summarized in Table 2. In both cell lines, potent cytotoxicity is observed under $\mathrm{N}_{2}$ and the high hypoxic selectivity is comparable to that observed using the antiproliferation assay discussed above.

Stability to Microsomal Enzymes. The lack of reactivity to microsomal enzymes is an important requirement for hypoxiaactivated prodrugs. This potential problem of being metabolized by microsomal enzymes is particularly relevant to phosphoramidates, because this class of compounds can be substrates for cytochrome P450 oxidation. Both of the clinically-used antitumor phosphoramidates, cyclophosphamide and ifosfamide, are substrates for and activated by cytochrome $\mathrm{P} 450$ in vivo. ${ }^{31}$

To assess the microsomal stability of the prodrug compounds, in vitro metabolic stability studies were performed in triplicate using mouse liver microsomes. When the compounds were treated with mouse liver microsomes for $30 \mathrm{~min}$ in the absence of NADPH, all compounds were stable. However, the treatment of the compounds with mouse liver microsomes in the presence of NADPH resulted in different stability profiles, as shown in Table 1 . The reactivity to cytochrome P450, as measured by mouse liver microsome stability, proved problematic for the alkyl-substituted phosphoramidates. Methyl substitution, $\mathbf{4 a}$, resulted in significantly reduced metabolic stability. The larger, more lipophilic alkyl groups of $\mathbf{4 b}$ resulted in the complete disappearance of the prodrug under the assay conditions. The enhanced lipophilicity of the alkyl-bearing prodrugs likely promotes cytochrome $\mathrm{P} 450$ oxidation of the prodrug. The methylenes adjacent to the phosphoramidate nitrogens could be predicted to be at risk for oxidation, given the known cytochrome P450 activation mechanism of cyclophosphamide and ifosfamide. ${ }^{31}$ However, other potential sites of oxidation cannot be excluded, including the methylene adjacent to the nitroimidazole. The observed cytochrome P450 liability of the alkyl substitutions focused our efforts on prodrugs with only hydrogen substitutions on the phosphoramidate nitrogens. These analogues consistently demonstrated enhanced stability to cytochrome P450 oxidation by liver microsomes. It is interesting to note that the previously reported ${ }^{17}$ racemic prodrug 6 is not as stable to microsomes as the symmetrical isomer, $\mathbf{5 a}$.

Aqueous Solubility of $\mathbf{3 b}$ and 5a. Solubility in aqueous systems is a desirable feature for pharmaceuticals. Compounds $\mathbf{3 b}$ and 5a demonstrated an aqueous solubility of 5.9 and 4.3 $\mathrm{mg} / \mathrm{mL}$, respectively, in saline (assay details in the Experimental Section).

Antitumor and Antimetastasis Efficacy of 3b and 5a in the MIA PaCa-2 Human Pancreatic Cancer Orthotopic Xenograft Model. To assess the in vivo antitumor efficacy of $\mathbf{3 b}$ and $\mathbf{5 a}$, these compounds were evaluated in animals bearing orthotopic MIA PaCa-2 human pancreatic cancer. ${ }^{32,33}$ This highly invasive and metastatic model was chosen for evaluation because it more closely replicates many of the characteristics of human disease. ${ }^{34}$ The surgical implantation of pancreatic tumor tissue on the pancreas of nude mice results in broadly disseminated disease. ${ }^{35}$ This is in contrast to the more traditional ectopic xenograft models, where tumors are grown subcutaneously on the flank of the animal and remain largely encapsulated.

Drug treatment was started day-3 after orthotopic implantation. Mice were randomized into 6 groups of 8 , each treated with vehicle (saline), 4-amino-1-(3,3-difluoro-4-hydroxy-5-hydroxymethyl-tetrahydrofuran-2-yl)- $1 H$-pyrimidin-2-one (gemcitabine) alone at 200 $\mathrm{mg} / \mathrm{kg}$, IP, once a week for 3 weeks, $\mathbf{3 b}$ alone at $30 \mathrm{mg} / \mathrm{kg}$, IP, once a day for 5 days a week for 15 days (11 total doses), 5a alone at $6 \mathrm{mg} / \mathrm{kg}$ once a day, IP, for 5 days a week for 15 days (11 total doses), or gemcitabine combined with $\mathbf{3 b}$ or $\mathbf{5 a}$, where $\mathbf{3 b}$ and 5a were given $2 \mathrm{~h}$ before gemcitabine administration on the days when both drugs were scheduled. The doses of $\mathbf{3 b}$ and 
Table 1. In Vitro Potency and Microsome Stability of Prodrugs

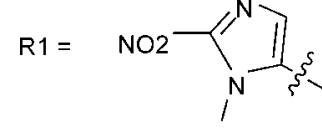

a<smiles>[Y][Z]1(C)CC=C([N+](=O)[O-])O1</smiles>

b<smiles>Cn1c([N+](=O)[O-])cnc1C(C)(C)C</smiles>

$\mathrm{c}$

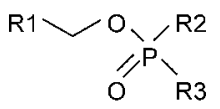

O

\begin{tabular}{|c|c|c|c|c|c|c|c|}
\hline \multirow[b]{2}{*}{ compound } & \multicolumn{3}{|c|}{ structure } & \multirow[b]{2}{*}{$\mathrm{IC}_{50}\left(\mathrm{~N}_{2}\right)^{a}(\mu \mathrm{M})$} & \multirow[b]{2}{*}{$\mathrm{IC}_{50}(\text { air })^{a}(\mu \mathrm{M})$} & \multirow[b]{2}{*}{$\mathrm{HCR}^{b}$} & \multirow[b]{2}{*}{ MLM stability $(\%)$} \\
\hline & $\mathrm{R}_{1}$ & $\mathrm{R}_{2}$ & $\mathrm{R}_{3}$ & & & & \\
\hline $3 \mathbf{a}$ & $\mathrm{a}$ & $\mathrm{NHCH}_{2} \mathrm{CH}_{2} \mathrm{Cl}$ & $\mathrm{R}_{3}=\mathrm{R}_{2}$ & $0.21 \pm 0.07$ & $88 \pm 11$ & 420 & 90 \\
\hline $3 \mathbf{b}$ & $\mathrm{a}$ & $\mathrm{NHCH}_{2} \mathrm{CH}_{2} \mathrm{Br}$ & $\mathrm{R}_{3}=\mathrm{R}_{2}$ & $0.019 \pm 0.008$ & $5.1 \pm 0.10$ & 270 & 92 \\
\hline $4 b$ & $\mathrm{a}$ & $\mathrm{N}\left(\mathrm{CH}_{2} \mathrm{CH}_{2} \mathrm{Cl}\right)_{2}$ & $\mathrm{R}_{3}=\mathrm{R}_{2}$ & $0.12 \pm 0.03$ & $27 \pm 5.3$ & 230 & 0 \\
\hline $5 a$ & $\mathrm{~b}$ & $\mathrm{NHCH}_{2} \mathrm{CH}_{2} \mathrm{Br}$ & $\mathrm{R}_{3}=\mathrm{R}_{2}$ & $0.083 \pm 0.004$ & $14 \pm 1.3$ & 170 & 79 \\
\hline $5 b$ & $\mathrm{c}$ & $\mathrm{NHCH}_{2} \mathrm{CH}_{2} \mathrm{Br}$ & $\mathrm{R}_{3}=\mathrm{R}_{2}$ & $5.7 \pm 1.0$ & $46 \pm 4.3$ & 8.0 & 92 \\
\hline
\end{tabular}

${ }^{a}$ Values are an average of six replicates with standard error (SE). ${ }^{b}$ Hypoxia cytotoxicity ratio (HCR) was determined by the differential cytotoxicity under normoxic and hypoxic conditions: $\mathrm{HCR}=\mathrm{IC}_{50}(\mathrm{air}) / \mathrm{IC}_{50}\left(\mathrm{~N}_{2}\right)$. The variability of the HCR can be estimated from the SEs of the individual IC $\mathrm{C}_{50}$ values. ${ }^{c}$ Percent of compound remaining after 30 min of incubation with mouse liver microsome $(\mathrm{CV}<6 \%)$. See the Experimental Section for details. ${ }^{d}$ Data not available.

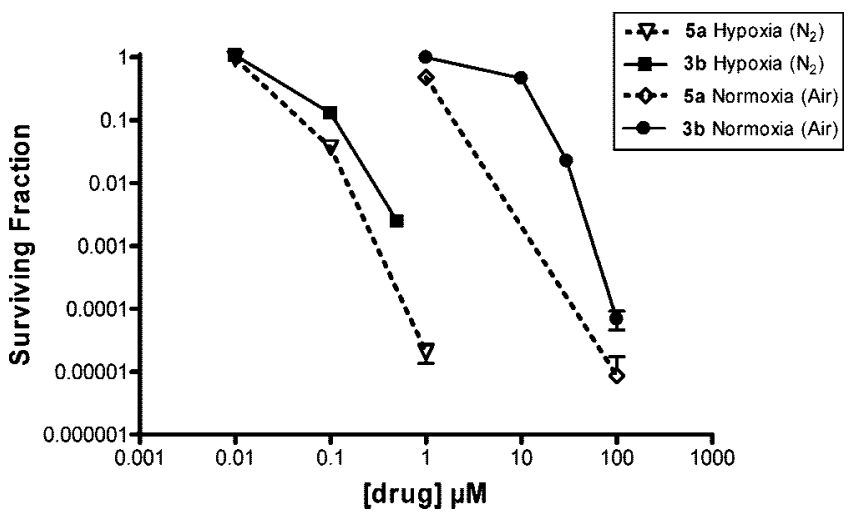

Figure 3. Clonogenic survival cytotoxicity assay results for $\mathbf{3 b}$ and 5a with $\mathrm{H} 460$ cells under hypoxia and normoxia. Assay details are in the Experimental Section. Data are averages of three replicates. All error bars are shown; some are obscured by the data points.

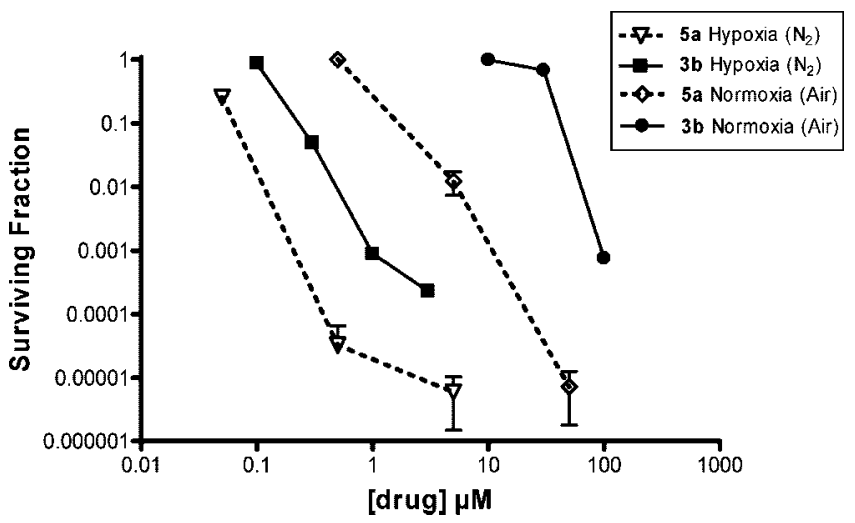

Figure 4. Clonogenic survival cytotoxicity assay results for $\mathbf{3 b}$ and 5a with HT29 cells under hypoxia and normoxia. Assay details are in the Experimental Section. Data are averages of three replicates. All error bars are shown; some are obscured by the data points.

5a were chosen on the basis of preliminary studies to define the MTD of each compound, when administered daily for 5 days. On the basis of weight loss and behavioral signs, the MTD of $\mathbf{3 b}$ was determined to be $100 \mathrm{mg} \mathrm{kg}^{-1}$ day $^{-1}$, and the MTD of 5a was determined to be $20 \mathrm{mg} \mathrm{kg}^{-1}$ day $^{-1}$. In the orthotopic study, both agents were administered at approximately one-third of the MTD. The dose of gemcitabine was two-thirds of the MTD for the drug as a single agent.
Table 2. Clonogenic Assay Data Summary for $\mathbf{3 b}$ and $\mathbf{5 a}$

\begin{tabular}{|c|c|c|c|c|c|c|}
\hline & \multicolumn{3}{|c|}{ 3b } & \multicolumn{3}{|c|}{$5 a$} \\
\hline & $\begin{array}{c}\mathrm{IC}_{90}\left(\mathrm{~N}_{2}\right) \\
(\mu \mathrm{M})\end{array}$ & $\begin{array}{c}\text { IC }_{90} \text { (air) } \\
(\mu \mathrm{M})\end{array}$ & HCR & $\begin{array}{c}\mathrm{IC}_{90}\left(\mathrm{~N}_{2}\right) \\
(\mu \mathrm{M})\end{array}$ & $\begin{array}{c}\text { IC }_{90} \text { (air) } \\
(\mu \mathrm{M})\end{array}$ & HCR \\
\hline H460 cells & 0.1 & 30 & 300 & 0.05 & 2 & 40 \\
\hline HT29 cells & 0.2 & 40 & 200 & 0.06 & 2 & 30 \\
\hline
\end{tabular}

Tumors grew rapidly in the vehicle-treated group after a lag of 10 days and eventually killed all of the mice by day 30 . Gemcitabine alone and $\mathbf{3 b}$ alone inhibited primary tumor growth by 82 and $41 \%$, respectively, on day 25 after implantation, whereas $3 \mathbf{b}$ plus gemcitabine inhibited primary tumor growth by $96 \%$ on day 25 (Figure 5). In addition, $3 \mathbf{b}$ plus gemcitabine significantly extended the survival time as illustrated in the Kaplan-Meier plots (Figure 6). Representative images of individual animal responses are shown in Figure 7. The median survival times in the vehicle, gemcitabine alone, $\mathbf{3 b}$ alone, and 5a alone groups were 26, 42, 28, and 27 days, respectively. In the $3 \mathbf{b}$ plus gemcitabine-treated group, the mice were sacrificed at day-44 and six of eight mice were alive at that time with one of the eight tumor-free (as assessed by open-body fluorescence imaging) (Figure 6). Only gemcitabine alone, 3b plus gemcitabine, and 5a plus gemcitabine significantly extended survival time compared to vehicle-treated controls $(p<0.001)$. Compound 5a plus gemcitabine failed to affect survival beyond that achieved by gemcitabine alone. However, $\mathbf{3 b}$ plus gemcitabine extended survival beyond that of gemcitabine alone $(p=0.05)$. Animal body weights were not affected by any treatment until the animals were near death because of the tumor burden.

Comparisons with Earlier 2-Nitroimidazole Drugs. Nitroimidazoles and related nitroazoles first undergo a one-electron reduction by ubiquitous cellular reductases, such as the NADPH cytochrome P450 reductase, as shown below in Figure $8 .^{36}$ Under low oxygen conditions, the radical anion has a sufficient lifetime to undergo further irreversible reductions to the hydroxylamine. In the case of $\mathbf{3 b}$, this is likely followed by phosphoramidate toxin elimination. Under normoxia, the reaction with oxygen results in a futile cycle, in which the radical anion is quenched, generating superoxide and reforming the starting nitroazole. The resulting superoxide can cause systematic background toxicity.

This normoxic superoxide production requires that prodrug constructs be sufficiently potent under hypoxic conditions to not require high doses for efficacy. More than 2 decades ago, 


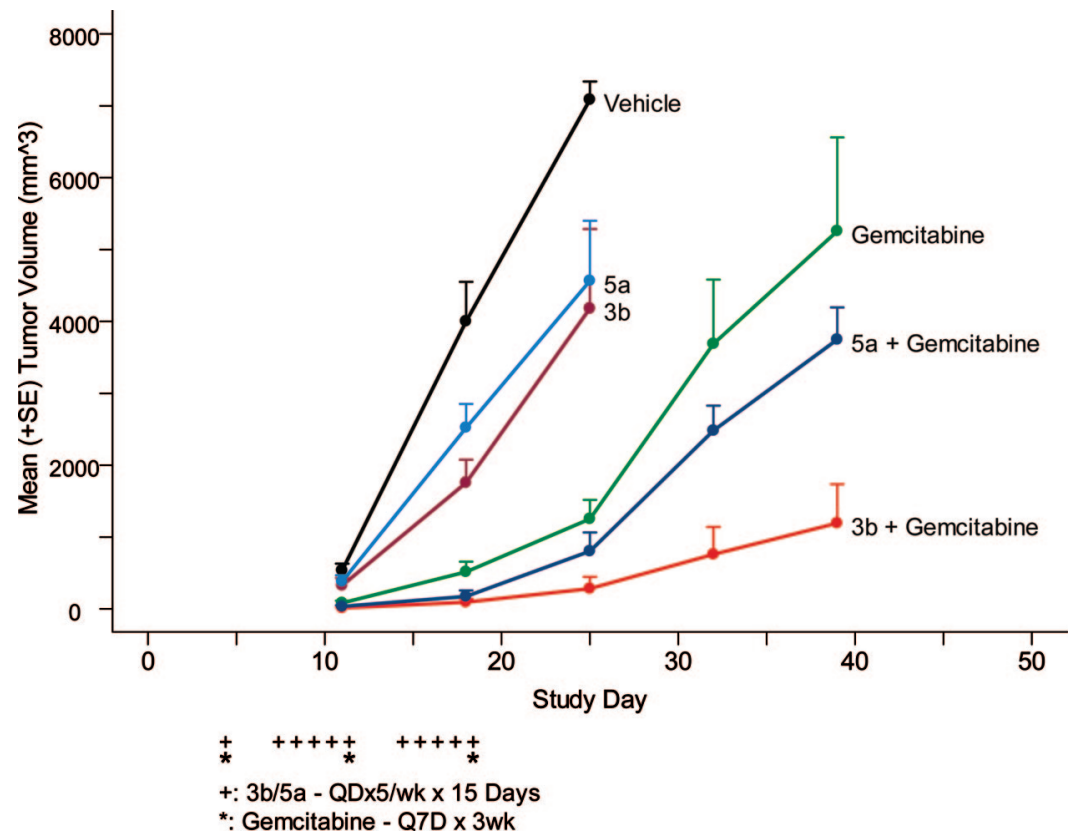

Figure 5. Disease progression measured by tumor volume in the MIA PaCa-2 human pancreatic cancer orthotopic model in nude mice after treatment with $\mathbf{3 b}$ or $\mathbf{5 a}$ alone or in combination with gemcitabine. The surgical orthotopic implantation was performed on Study Day 1. * denotes days of gemcitabine dosing, and + denotes days of $\mathbf{3 b}$ and $\mathbf{5 a}$ dosing. Means are plotted with standard errors of the mean. Groups with less than 3 animals are not included in plot. All individual animal plots are included in Supporting Information.

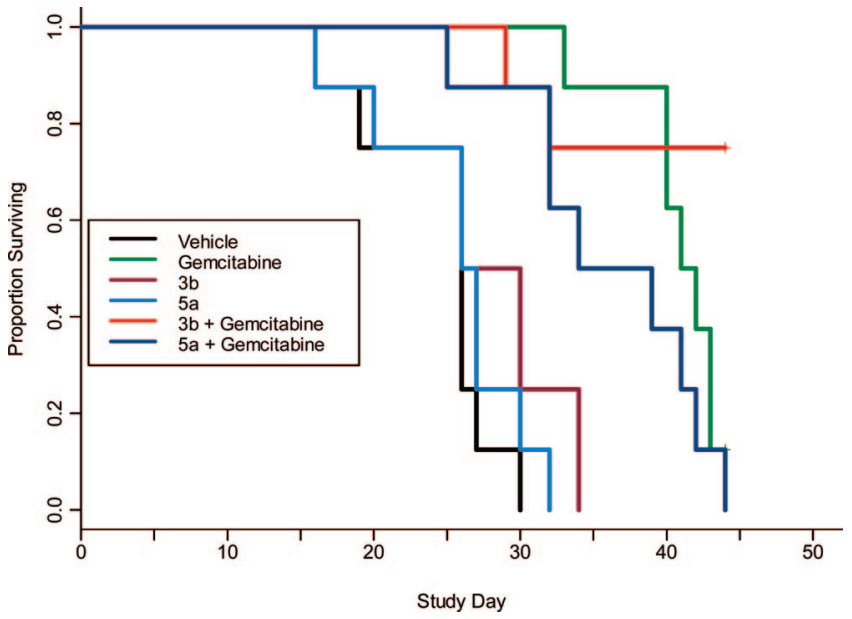

Figure 6. Survival data (Kaplan-Meier graph) of MIA PaCa-2 human pancreatic cancer orthotopic model in nude mice after treatment with $\mathbf{3 b}$ or $\mathbf{5 a}$ alone or in combination with gemcitabine.

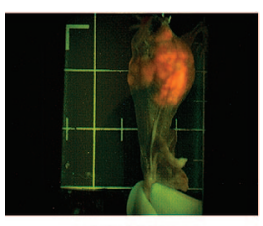

Vehicle

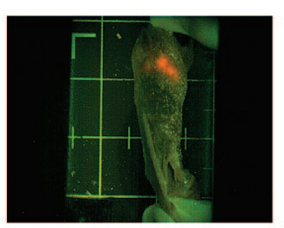

Gemcitabine

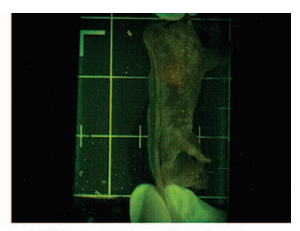

$\mathbf{3 b}+$ Gemcitabine
Figure 7. Representative images from whole body fluorescent imaging of control and treated animals. Data were obtained on day 17 of the study. Details are in the Experimental Section.

the simple 2-nitroimidazole, misonidazole (Figure 9), was explored clinically as a hypoxia-activated prodrug and radiation sensitizer. ${ }^{37}$ Because of low potency, very high doses were required (total dose, $11 \mathrm{~g} / \mathrm{m}^{2}$ ) and neuropathy, likely caused by the super oxide, was observed. ${ }^{38}$ More potent 2-nitroimidazole derivatives were subsequently explored. 1-(Aziridine-1yl)-3-(2nitro-1H-imidazol-1-yl)propan-2ol (RSU-1069, 7, Figure 9), ${ }^{39}$ a 2-nitroimidazole derivative conjugated to an alkylating aziridine, suffered from the fact that the aziridine alkylator was not triggered by the nitroimidazole reduction and hence was always active. This aziridine function was believed to be responsible for the toxicity seen in humans. ${ }^{40}$ While more potent than misonidazole, 7 was also characterized by relatively low potency under hypoxic conditions, with a reported $\mathrm{IC}_{50}$ value under $\mathrm{N}_{2}$ of $15 \mu \mathrm{M}$ in $\mathrm{V} 79-379 \mathrm{~A}$ cells. ${ }^{39} \mathrm{~A}$ prodrug of $7,{ }^{41} 1-(2-$ bromoethylamino)-3-(2-nitro-1H-imidazol-1-yl)propan-2-ol hydrobromide (RB-6145, 8, Figure 9), ${ }^{42}$ has shown reduced toxicity but without significant improvement in efficacy. 2-Nitroimidazole intercalator conjugates, such as 7-chloro- $N$-(3-(2nitro-1H-imidazol-1-yl)propyl)quinolin-4-amine (NLCQ-1, 9, Figure 9), ${ }^{43}$ have also been investigated preclinically but demonstrate similar low potency under hypoxia, as observed with 7 .

These early 2-nitroimidazole agents also differ mechanistically from 3b. As described above in Figure 8, upon reduction to the hydroxylamine, $\mathbf{3 b}$ likely releases a diffusible DNA-crosslinking toxin. The earlier agents, upon hypoxic reduction to the hydroxylamine, use a well-characterized nitrenium ion formation, resulting in a monoalkylator. ${ }^{44}$ These early derivatives had such weak hypoxic potencies that high concentrations were required for effective killing under hypoxia, and hence, high doses were required for efficacy. The potency and hypoxia selectivity of $\mathbf{3 b}$ could allow it to be efficacious at lower doses compared to the earlier agents described above and thus avoiding the systemic toxicity generated by superoxide ${ }^{36}$ and potentially other off-target effects.

Compound $\mathbf{3 b}$, an achiral phosphoramidate mustard prodrug, demonstrates potent hypoxia-dependent cytotoxicity and stability to microsomal metabolism and is efficacious as a monotherapy. It demonstrates dramatic antitumor efficacy in combination with gemcitabine in an orthotopic human pancreatic cancer model in nude mice. Because of its attractive preclinical properties, $\mathbf{3 b}$ is undergoing phase-1 clinical testing for the treatment of solid tumors. 

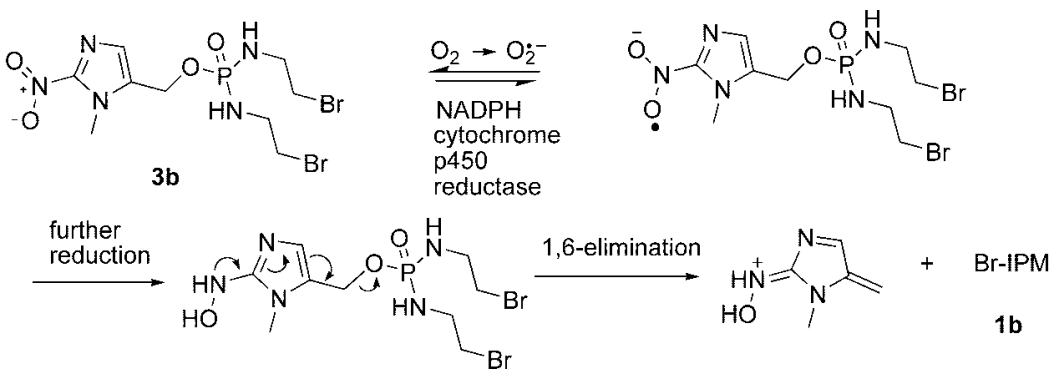

Figure 8. Postulated reduction pathway of $\mathbf{3 b}$ yielding Br-IPM toxin (1b).<smiles>COCC(O)Cn1ccnc1[N+](=O)[O-]</smiles><smiles>O=[N+]([O-])c1nccn1CC(O)CNCCBr</smiles>

8 misonidazole
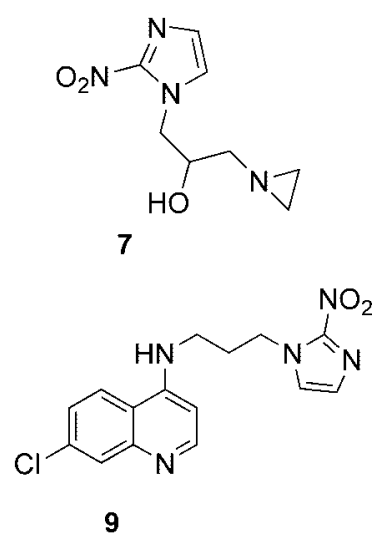

Figure 9. Structures of misonidazole, 7, 8, and $\mathbf{9 .}$

\section{Experimental Section}

${ }^{1} \mathrm{H}$ and ${ }^{13} \mathrm{C}$ nuclear magnetic resonance (NMR) spectra were recorded on a Varian $400 \mathrm{MHz}$ spectrometer $(400$ and $75 \mathrm{MHz}$, respectively) using $\mathrm{CDCl}_{3}, \mathrm{CD}_{3} \mathrm{OD}$, or DMSO- $d_{6}$ as solvents with TMS as an internal standard. High-resolution mass spectra analysis was performed on a GCT-MS Micromass UK mass spectrometer. Column chromatography was performed with silica gel (230-400 mesh). All of the starting materials are commercially available and were used without further purification.

Compounds $\mathbf{1 a}$ and $\mathbf{1 b}$ were synthesized using a similar method. A typical procedure can be described as follows using 1a as the example: To a suspension of 2-chloroethylamine hydrochloride (7.2 $\mathrm{g}, 62 \mathrm{mmol})$ in DCM $(110 \mathrm{~mL})$ was added $\mathrm{POCl}_{3}(2.84 \mathrm{~mL}, 31$ mmol) slowly from -10 to $-15^{\circ} \mathrm{C}$ with vigorous stirring, followed by the addition of a solution of TEA $(17.5 \mathrm{~mL}, 124 \mathrm{mmol})$ in DCM $(30 \mathrm{~mL})$ over $1 / 2 \mathrm{~h}$. The reaction mixture was stirred below -10 ${ }^{\circ} \mathrm{C}$ for $2 \mathrm{~h}$. The resulting solid was filtered and washed with cooled DCM $(5 \mathrm{~mL})$. The filtrate was concentrated under vacuum to about $30 \mathrm{~mL}$. The residue was filtered, and the solid was washed with cooled DCM $(5 \mathrm{~mL})$. The filtrate was concentrated under vacuum to dryness. The residue was then dissolved in THF $(7 \mathrm{~mL})$ and mixed with water $(10 \mathrm{~mL})$. The mixture was stirred at room temperature for $2 \mathrm{~h}$. THF was removed under vacuum, and the aqueous solution was kept at $4{ }^{\circ} \mathrm{C}$ overnight. The crystalline solid was filtered and washed with cold water and ether. After the product was dried under vacuum overnight, 1a (3 g) was obtained in $46 \%$ yield as a white solid. ${ }^{31} \mathrm{P}$ NMR (DMSO- $\left.d_{6}\right) \delta: 14.17 \mathrm{ppm}$. The chemical shift of ${ }^{31} \mathrm{P}$ NMR is in agreement with the reported data. ${ }^{45}$ Compound $\mathbf{1 b}{ }^{46}$ was obtained in $40 \%$ yield. ${ }^{1} \mathrm{H}$ NMR (DMSO- $d_{6}$ ) $\delta: 5.10$ (br, 3H), 3.42 (t, $J=7.2 \mathrm{~Hz}, 4 \mathrm{H}), 3.07$ (dt, $J=12.4,7.2$ $\mathrm{Hz}, 4 \mathrm{H})$.

1-Methyl-2-nitro-1 $H$-imidazol-5-yl)methyl $N, N$-bis(2-chloroethyl)phosphordiami-date (3a). To a suspension of compound 1a (127 mg, $0.58 \mathrm{mmol}$ ), 2, 1-methyl-2-nitroimidazole-5-methanol (180 $\mathrm{mg}, 1.15 \mathrm{mmol})$, and $\mathrm{PPh}_{3}(300 \mathrm{mg}, 1.15 \mathrm{mmol})$ in THF (15 mL) was added DIAD $(0.22 \mathrm{~mL}, 1.15 \mathrm{mmol})$ at $0{ }^{\circ} \mathrm{C}$. After the addition of DIAD, the reaction mixture was warmed to room temperature and stirred for $2 \mathrm{~h}$. The solvent was removed, and the residue was purified by flash chromatography (acetone in toluene from 0 to $70 \%$ ) to give product 3a (130 mg, 63\%). ${ }^{1} \mathrm{H}$ NMR (DMSO- $\left.d_{6}\right) \delta: 7.13$ $(\mathrm{s}, 1 \mathrm{H}), 4.97(\mathrm{~d}, J=7.6 \mathrm{~Hz}, 2 \mathrm{H}), 3.99(\mathrm{~s}, 3 \mathrm{H}), 3.50(\mathrm{~m}, 6 \mathrm{H})$, and $3.15(\mathrm{~m}, 4 \mathrm{H}) .{ }^{13} \mathrm{C}$ (DMSO- $\left.d_{6}\right) \delta: 146.01,134.17(\mathrm{~d}, J=26.4 \mathrm{~Hz})$, 128.13, 55.55, 44.99 (d, $J=18 \mathrm{~Hz}), 42.65,34.25 .{ }^{31} \mathrm{P} \mathrm{NMR}$ $\left(\mathrm{DMSO}-d_{6}\right) \delta:-10.88$. High-resolution mass spectrometry (HRMS): Calcd for $\mathrm{C}_{9} \mathrm{H}_{16} \mathrm{~N}_{5} \mathrm{O}_{4} \mathrm{PCl}_{2}, 359.0317$; found, 359.0314.

1-Methyl-2-nitro-1H-imidazol-5-yl)methyl $N, N$-bis(2-bromoethyl)phosphordiami-date (3b). Compound $\mathbf{3 b}$ was synthesized by a procedure similar to that described for $\mathbf{3 a}$ and obtained as an off-white solid in $47.6 \%$ yield. ${ }^{1} \mathrm{H}$ NMR (DMSO- $\left.d_{6}\right) \delta: 7.22(\mathrm{~s}$, $1 \mathrm{H}), 5.10-5.00(\mathrm{~m}, 2 \mathrm{H}), 4.97$ (d, $J=7.6 \mathrm{~Hz}, 2 \mathrm{H}), 3.94$ (s, 3H), $3.42(\mathrm{t}, J=7.2 \mathrm{~Hz}, 4 \mathrm{H})$, and $3.00-3.20(\mathrm{~m}, 4 \mathrm{H}) .{ }^{13} \mathrm{C}$ NMR (DMSO$\left.d_{6}\right) \delta: 146.04,134.16(\mathrm{~d}, J=32 \mathrm{~Hz}), 128.17,55.64,42.70,34.33$, and $34.11(\mathrm{~d}, J=17.2 \mathrm{~Hz}) .{ }^{31} \mathrm{P}$ NMR (DMSO- $\left.d_{6}\right) \delta:-11.25$. HRMS: Calcd for $\mathrm{C}_{9} \mathrm{H}_{16} \mathrm{~N}_{5} \mathrm{O}_{4} \mathrm{PBr}_{2}$, 446.9307; found, 446.9294.

1-Methyl-2-nitro-1H-imidazol-5-yl)methyl $N, N$-bis(2-chloroethyl)- $N, N$-dimethyl-phosphordiamidate (4a). A suspension of $\mathrm{N}$-methyl-2-chloroethylamine hydrochloride $(10 \mathrm{~g})$ in $\mathrm{POCl}_{3}(40$ $\mathrm{mL}$ ) was refluxed overnight. After $\mathrm{POCl}_{3}$ was removed under vacuum, $N$-methyl- $N$-(2-chloroethyl)dichlorophosphoramidate was distilled out under vacuum. To a mixture of $N$-methyl- $N$-(2chloroethyl)dichlorophosphoramidate ( $1 \mathrm{~g}, 4.75 \mathrm{mmol}$ ) and $\mathrm{N}$-methyl-2-chloroethylamine hydrochloride $(0.62 \mathrm{~g}, 4.75 \mathrm{mmol})$ in THF $(30 \mathrm{~mL})$ was added DIEA $(1.65 \mathrm{~mL}, 9.5 \mathrm{mmol})$ slowly at $-78{ }^{\circ} \mathrm{C}$. After the addition of DIEA, the reaction mixture was warmed to room temperature and stirred for $1 \mathrm{~h}$. The reaction was diluted with ethyl acetate $(200 \mathrm{~mL})$, and the resulting solution was washed with brine $(200 \mathrm{~mL})$. The organic layer was dried with $\mathrm{MgSO}_{4}$ and concentrated. The residue was purified by flash chromatography (ethyl acetate in hexane from 35 to $75 \%$ ) to give the oil product $N, N$-bis(chloroethyl)- $N, N$-dimethyl-chlorophosphordiamidate. ${ }^{1} \mathrm{H}$ NMR (DMSO- $\left.d_{6}\right) \delta: 4.1(\mathrm{~s}, 3 \mathrm{H}), 3.82-3.70(\mathrm{~m}, 4 \mathrm{H}), 3.6-3.3(\mathrm{~m}$, $4 \mathrm{H})$, and $2.7(\mathrm{~d}, J=12.4 \mathrm{~Hz}, 6 \mathrm{H})$.

To a solution of $N$-methyl-2-nitroimidazolyl methanol $(0.5 \mathrm{~g}$, $3.2 \mathrm{mmol})$ in DME $(10 \mathrm{~mL})$ was added lithium bis(trimethylsily1)amide ( $1 \mathrm{M}$ in THF, $3.2 \mathrm{~mL}, 3.2 \mathrm{mmol})$ at $-78^{\circ} \mathrm{C}$. The reaction mixture was stirred for $5 \mathrm{~min}$, and $N, N$-bis(chloroethyl)- $N, N$ dimethyl-chlorophosphordiamidate $(770 \mathrm{mg}, 2.9 \mathrm{mmol}$ ) was added at $-78^{\circ} \mathrm{C}$. After the reaction solution was slowly warmed to -20 ${ }^{\circ} \mathrm{C}$, the reaction solution was diluted with ethyl acetate $(50 \mathrm{~mL})$ and washed with brine $(50 \mathrm{~mL})$. The organic layer was dried with $\mathrm{MgSO}_{4}$ and concentrated under vacuum. The residue was purified by flash chromatography (methanol in DCM from 6 to $12 \%$ ) to produce 4a $(530 \mathrm{mg}, 47 \%) .{ }^{1} \mathrm{H}$ NMR $\left(400 \mathrm{MHz}, \mathrm{DMSO}-d_{6}\right) \delta$ : $7.22(\mathrm{~s}, 1 \mathrm{H}), 5.11(\mathrm{~d}, J=8.8 \mathrm{~Hz}, 2 \mathrm{H}), 3.95(\mathrm{~s}, 3 \mathrm{H}), 3.70(\mathrm{t}, J=$ $6.8 \mathrm{~Hz}, 4 \mathrm{H}), 3.26-3.18(\mathrm{~m}, 4 \mathrm{H})$, and $2.57(\mathrm{~d}, J=9.6 \mathrm{~Hz}, 6 \mathrm{H}) .{ }^{13} \mathrm{C}$ NMR (DMSO- $\left.d_{6}\right) \delta: 146.10,133.72(\mathrm{~d}, J=28.8 \mathrm{~Hz}), 128.20$, $55.66,50.29(\mathrm{~d}, J=17.2 \mathrm{~Hz}), 42.16,34.21$, and $33.41(\mathrm{~d}, J=$ $17.2 \mathrm{~Hz}$ ). ${ }^{31} \mathrm{P}$ NMR (DMSO) $\delta$ : -8.49 . HRMS: Calcd for $\mathrm{C}_{11} \mathrm{H}_{21} \mathrm{~N}_{5} \mathrm{O}_{4} \mathrm{PCl}_{2}$, 388.0708; found, 388.0713.

1-Methyl-2-nitro-1H-imidazol-5-yl)methyl $N, N, N, N$-tetrakis(2chloroethyl)-dimethylphosphordiamidate $(\mathbf{4 b})$. To a suspension of bis(2-chloroethyl)amine hydrochloride (1.43 g, $8.01 \mathrm{mmol})$ in DCM $(20 \mathrm{~mL})$ was added phosphorus trichloride $(0.32 \mathrm{~mL}, 3.64$ $\mathrm{mmol})$ at room temperature, followed by the addition of TEA (3.05 $\mathrm{mL}, 21.84 \mathrm{mmol})$. The reaction mixture was stirred at room 
temperature for $1 / 2 \mathrm{~h}$ and then 2, N-methyl 2-nitroimidazolyl methanol $(0.474 \mathrm{~g}, 3.31 \mathrm{mmol})$, in DCM $(10 \mathrm{~mL})$ was added. After stirring for another $1 / 2 \mathrm{~h}$, the reaction was cooled to $-20{ }^{\circ} \mathrm{C}$ and then tert-butyl hydroperoxide ( $0.7 \mathrm{~mL}, 3.82 \mathrm{mmol}, 5.5 \mathrm{M}$ in decane) was added. The mixture was warmed to room temperature in $1 \mathrm{~h}$ and poured into a $10 \% \mathrm{HCl}$ aqueous solution $(30 \mathrm{~mL})$. The organic layer was separated, and the aqueous layer was extracted with DCM $(50 \mathrm{~mL})$. The combined organic solution was dried over $\mathrm{MgSO}_{4}$, filtered, and concentrated under vacuum. The residue was subjected to flash chromatography (methanol in DCM at 6-12\%) to give $\mathbf{4 b}$ (350 mg, 20\% yield). ${ }^{1} \mathrm{H}$ NMR (DMSO- $\left.d_{6}\right) \delta: 7.28$ (s, 1H), 5.14 $(\mathrm{d}, J=8.4 \mathrm{~Hz}, 2 \mathrm{H}), 3.95(\mathrm{~s}, 3 \mathrm{H}), 3.69(\mathrm{t}, J=6.8 \mathrm{~Hz}, 4 \mathrm{H})$, and $3.33(\mathrm{~m}, 4 \mathrm{H}) .{ }^{13} \mathrm{C}$ NMR (DMSO- $\left.d_{6}\right) \delta: 146.24,132.15(\mathrm{~d}, J=30$ $\mathrm{Hz}), 129.26,56.27,49.09$ (d, $J=15.2 \mathrm{~Hz}), 42.11$, and $34.31 .{ }^{31} \mathrm{P}$ NMR (DMSO- $d_{6}$ ) $\delta$ : -9.69 . HRMS: Calcd for $\mathrm{C}_{13} \mathrm{H}_{23} \mathrm{~N}_{5} \mathrm{O}_{4} \mathrm{PCl}_{4}$, 484.0242; found, 484.0247.

5-Nitrofuran-2-yl)methyl $N, N$-bis(2-bromoethyl)phosphordiamidate (5a). Compound 5a was synthesized by a procedure similar to that used for the synthesis of $\mathbf{3 b}$ and was obtained as a yellow oil in 50\% yield. ${ }^{1} \mathrm{H}$ NMR (DMSO- $\left.d_{6}\right) \delta: 7.68(\mathrm{~d}, J=3.6$ $\mathrm{Hz}, 1 \mathrm{H}), 6.09(\mathrm{~d}, J=3.6 \mathrm{~Hz}, 1 \mathrm{H}), 5.05(\mathrm{~m}, 2 \mathrm{H}), 4.94(\mathrm{~d}, J=8.4$ $\mathrm{Hz}, 2 \mathrm{H}), 3.44(\mathrm{t}, J=6.8 \mathrm{~Hz}, 4 \mathrm{H})$, and $3.12(\mathrm{~m}, 4 \mathrm{H}) .{ }^{13} \mathrm{C} \mathrm{NMR}$ $\left(\mathrm{DMSO}-d_{6}\right) \delta: 154.54(\mathrm{~d}, J=30 \mathrm{~Hz}), 151.54,113.58,113.31$, $58.09,42.70$, and $33.90(\mathrm{~d}, J=40 \mathrm{~Hz}) .{ }^{31} \mathrm{P}$ NMR (DMSO- $\left.d_{6}\right) \delta$ : -11.05. HRMS: Calcd for $\mathrm{C}_{9} \mathrm{H}_{15} \mathrm{~N}_{3} \mathrm{O}_{5} \mathrm{PBr}_{2}, 433.9116$; found, 433.9122 .

1-Methyl-5-nitro-1H-imidazol-2-yl)methyl $N, N$-bis(2-bromoethyl)phosphordiamidate (5b). Compound $\mathbf{5 b}$ was synthesized by a similar procedure for the synthesis of $\mathbf{3} \mathbf{b}$ and was obtained as a white solid in $51 \%$ yield. ${ }^{1} \mathrm{H}$ NMR $\left(\mathrm{CDCl}_{3}\right) \delta: 7.88(\mathrm{~s}, 1 \mathrm{H}), 5.01$ (d, $J=8 \mathrm{~Hz}, 2 \mathrm{H}), 3.97$ (s, 3H), 3.59 (br, 2H), 3.36 (t, $J=6 \mathrm{~Hz}$, $4 \mathrm{H})$, and $3.23(\mathrm{~m}, 4 \mathrm{H}) .{ }^{13} \mathrm{C}$ NMR (DMSO- $\left.d_{6}\right) \delta: 147.21(\mathrm{~d}, J=$ $29.2 \mathrm{~Hz}), 139.61,131.83,58.89(\mathrm{~d}, J=17.2 \mathrm{~Hz}), 42.88,34.55$ (m), and 33.72. ${ }^{31} \mathrm{P} \mathrm{NMR}\left(\mathrm{CDCl}_{3}\right) \delta:-10.63$. HRMS $(\mathrm{M}+\mathrm{Na})$ : Calcd for $\mathrm{C}_{9} \mathrm{H}_{16} \mathrm{~N}_{5} \mathrm{O}_{4} \mathrm{PBr}_{2} \mathrm{Na}$, 469.9204; found, 469.9210 .

In Vitro Cell-Proliferation Assay. H460 cells (ATCC) were cultured in RPMI 1640 medium supplemented with $10 \%$ fetal bovine serum and $1 \%$ penicillin-streptomycin (Gibco/Invitrogen) in a $5 \% \mathrm{CO}_{2}$ humidified environment at $37^{\circ} \mathrm{C}$. Cells were seeded 1 day before the experiment in glass inserts placed in each well of a 24-well plate at a density of 20000 cells/well with $500 \mu \mathrm{L}$ of medium. The next day, serial dilutions of test compounds in DMSO were made in RPMI medium, such that final concentrations of DMSO did not exceed $1 \%$. Medium was removed from the cells, and $200 \mu \mathrm{L}$ of test compound in RPMI was added directly to cells in glass inserts. The cells in the hypoxia treatment group were incubated for $2 \mathrm{~h}$ in a Bactron II anaerobic chamber flushed with a certified anaerobic gas mixture $\left(90 \% \mathrm{~N}_{2} / 5 \% \mathrm{CO}_{2} / 5 \% \mathrm{H}_{2}\right.$; Praxair). The cells in the air treatment group were incubated for $2 \mathrm{~h}$ in standard tissue-culture incubators. After the $2 \mathrm{~h}$ of treatment with test compounds, the cells were washed with $500 \mu \mathrm{L}$ of medium and incubated for 3 days in $500 \mu \mathrm{L}$ of fresh medium. After 3 days, the cells were stained with $10 \%$ AlamarBlue for $2 \mathrm{~h}$, after which the viability of cells was measured by a fluorescence plate reader (Tecan Safire2) at an excitation wavelength of $550 \mathrm{~nm}$ and an emission wavelength of $590 \mathrm{~nm}$. The $50 \%$ inhibitory concentration $\left(\mathrm{IC}_{50}\right)$ of test compounds was calculated from results of two independent experiments $(n=6)$.

In Vitro Clonogenic Assay. Exponentially growing human H460 or HT29 cells (ATCC) were seeded into $60 \mathrm{~mm}$ notched glass plates at $\sim 3 \times 10^{5}$ cells per plate and grown in RPMI medium supplemented with $10 \%$ fetal bovine serum (Gibco/ Invitrogen) for 2 days prior to initiating treatment. On the day of the test, drug stocks of known concentrations were prepared in complete medium and $2 \mathrm{~mL}$ of the desired stock was added to each plate. The plates were placed in either an anaerobic chamber (Bacron II) or a standard tissue-culture incubator. The anaerobic chamber was evacuated and gassed with the anaerobic gas mixture $\left(90 \% \quad \mathrm{~N}_{2} / 5 \% \quad \mathrm{CO}_{2} / 5 \% \mathrm{H}_{2}\right.$; Praxair) to create an hypoxic environment. Cells were then incubated with the drug for $2 \mathrm{~h}$ at $37^{\circ} \mathrm{C}$. At the end of treatment, plates were removed from each vessel and washed with phosphate-buffered saline and a solution of trypsin-EDTA and then trypsinized for $5 \mathrm{~min}$ at $37^{\circ} \mathrm{C}$. Detached cells were neutralized with medium plus serum and spun for $5 \mathrm{~min}$ at $100 \mathrm{~g}$. Cells were resuspended at approximately $1 \times 10^{6}$ cells $/ \mathrm{mL}$ and diluted 10 -fold for plating. The exact concentration of each stock was determined by counting with a Coulter Z2 particle counter. Known numbers of cells were plated and placed undisturbed in an incubator for between 9 and 13 days. Colonies were fixed and stained with a solution of $95 \%$ ethanol with $0.25 \%$ crystal violet stain. Colonies of greater than 50 cells were counted, and the surviving fraction was determined. Plating efficiencies (PEs) were determined by dividing the number of colonies by the actual number of cells plated. Surviving fractions were calculated by dividing the PEs of treated cells by the PEs of untreated cells.

Procedure for Mouse Liver Microsome Stability Assay. The incubation mixtures of test compounds with mouse liver microsomes contained the following at the indicated final concentrations: $50 \mathrm{mM}$ potassium phosphate buffer ( $\mathrm{pH} 7.4)$ and $5 \mathrm{mM}$ $\mathrm{MgCl}_{2}$, microsomes $(1 \mathrm{mg} / \mathrm{mL})$ with or without $2 \mathrm{mM} \mathrm{NADPH}$. The mixtures were preincubated at $37{ }^{\circ} \mathrm{C}$. The metabolism reaction (in triplicate) was initiated by the addition of $5 \mu \mathrm{M}$ test compound to the incubation mixture. At 10, 20, and $30 \mathrm{~min}$, the reaction mixture was quenched using $280 \mu \mathrm{L}$ of a quenching solution containing $0.1 \%$ formic acid/acetonitrile. The samples were centrifuged at $4{ }^{\circ} \mathrm{C}$ for $10 \mathrm{~min}$ at $3000 \mathrm{~g}$. The supernatant was transferred to a vial for analysis using a generic LC-MS method. The microsomal activity was monitored using testosterone as a positive control.

Aqueous Solubility Assessment. A total of $100 \mathrm{mg}$ of $\mathbf{3 b}$ was mixed with $4.0 \mathrm{~mL}$ of saline $(140 \mathrm{mM} \mathrm{NaCl}$ and $10 \mathrm{mM}$ phosphate at $\mathrm{pH} 7.4$ ), vortexed for $5 \mathrm{~min}$, and allowed to sit at room temperature for $1 \mathrm{~h}$ followed by filtration (PVDF, 0.45 $\mu \mathrm{m})$. All preparations were performed in duplicate. Aliquots of each individual sample were appropriately diluted and analyzed by HPLC using $\mathbf{3 b}$ as a reference standard. The concentration in each sample was calculated from the area response of the $\mathbf{3 b}$ standard peak. Solubility of 5a was determined similarly.

Orthotopic Xenograft Model of Pancreatic Cancer. Orthotopic tumors were generated using MIA PaCa-2-RFP cells as previously described. $^{32-35}$ Tumor stocks were made by subcutaneously injecting the MIA PaCa-2 cells expressing red fluorescent protein (RFP) at a concentration of $5 \times 10^{6}$ cells in $200 \mu \mathrm{L}$ of serum-free medium into the flanks of nude mice. Two tumor fragments $\left(1 \mathrm{~mm}^{3}\right)$ from a subcutaneous tumor were implanted onto the middle of the pancreas in each nude mouse. The pancreas was returned to the peritoneal cavity, and the incision in the abdominal wall and skin was closed with surgical sutures in two layers. The animals were kept under isoflurane anesthesia during surgery.

During the course of the study, the primary tumor size for each animal was followed on a weekly basis by analyzing fluorescent images. Briefly, the mice were placed in a fluorescent light box equipped with a fiberoptic light source of $490 \mathrm{~nm}$ (Lightools Research, Encinitas, CA). Selective excitation of RFP was produced through a D425/60 band-pass filter and 470 DCXR dichroic mirror. Emitted fluorescence was collected through a long-pass filter GG475 (Chroma Technology, Brattleboro, VT) on a Hamamatsu C5810 3 chip-cooled color-charge-coupled device camera (Hamamatsu Photonics, Bridgewater, NJ). Images were processed for contrast and brightness and analyzed with the use of Image Pro Plus 3.1 software (Media Cybernetics, Silver Spring, Maryland). High-resolution images of $1024 \times 724$ pixels were captured directly on an IBM PC or continuously through video output on a high-resolution Sony VCR (model SLV-R1000; Sony, Tokyo).

Real-time determination of tumor burden was performed by quantifying red fluorescent surface area. The tumor volume was calculated using the following formula: tumor volume $\left(\mathrm{mm}^{3}\right)=$ $\left[(\text { width })^{2} \times\right.$ length $] / 2$. The end points for evaluating antitumor activity were tumor growth inhibition, survival time from KaplanMeier plots, and the number of complete tumor cures. The median survival was also calculated as the time at which half of the animals 
have died in the Kaplan-Meier plot. Statistical significance between the treated groups versus the vehicle control group or the chemotherapy control was evaluated by the log rank test using Prism GraphPad software.

Note Added after ASAP Publication. This manuscript was released ASAP on February 8, 2008, with errors in the in vivo data that affected the following areas: text near the end of the abstract, text in the last paragraph of the second column of the third page, text in the second column of the fourth page, Figures 5 and 6, the caption to Figure 5, and the Supporting Information. The current version was posted on March 21, 2008.

Supporting Information Available: Characterization $\left({ }^{1} \mathrm{H}\right.$ and ${ }^{13} \mathrm{C}$ NMR spectra and HRMS), purities of all of the new compounds from normal- and reverse-phase HPLC analyses and individual animal tumor growth plots. This information is available free of charge via the Internet at http://pubs.acs.org.

\section{References}

(1) Gillies, R. J.; Gatenby, R. A. Hypoxia and adaptive landscapes in the evolution of carcinogenesis. Cancer Metastasis Rev. 2007, 26, 311317.

(2) Brown, J. M.; Wilson, W. R. Exploiting tumour hypoxia in cancer treatment. Nat. Rev. Cancer 2004, 4, 437-447.

(3) Williams, K. J.; Cowen, R. L.; Brown, L. M.; Chinje, E. C.; Jaffar, M.; Stratford, I. J. Hypoxia in tumors: Molecular targets for anti-cancer therapeutics. Adv. Enzyme Regul. 2004, 44, 93-108.

(4) Welsh, S. J.; Koh, M. Y.; Powis, G. The hypoxia inducible stress reponse as a target for cancer drug discovery. Semin. Oncol. 2006, 33, 486-497.

(5) Boyle, R. G.; Travers, S. Hypoxia: Targeting the tumor. Anticancer Agents Med. Chem. 2006, 6, 281-286.

(6) Ahn, G. O.; Brown, M. Targeting tumors with hypoxia-activated cytotoxins. Front. Biosci. 2007, 12, 3483-3501.

(7) McKeown, S. R.; Cowen, R. L.; Williams, K. J. Bioreductive drugs: From concept to clinic. Clin. Oncol. 2007, 19, 427-442.

(8) Teicher, B. A.; Sartorelli, A. C. Nitrobenzyl halides and carbamates as prototype bioreductive alkylating agents. J. Med. Chem. 1980, 23, 955-960.

(9) Zeman, E. M.; Brown, J. M.; Lemmon, M. J.; Hirst, V. K.; Lee, W. W. SR-4233: A new bioreductive agent with high selective toxicity for hypoxic mammalian cells. Int. J. Radiat. Oncol., Biol., Phys. 1986, $12,1239-1242$.

(10) Denny, W. A.; Wilson, W. R. Tirapazamine: A bioreductive anticancer drug that exploits tumor hypoxia. Expert Opin. Invest. Drugs 2000, 9, 2889-2901.

(11) Hicks, K. O.; Fleming, Y.; Siim, B. G.; Koch, C. J.; Wilson, W. R. Extravascular diffusion of tirapazamine: Effect of metabolic consumption assessed using the multicellular layer model. Int. J. Radiat. Oncol., Biol., Phys. 1998, 42, 641-649.

(12) Kyle, A. H.; Minchinton, A. I. Measurement of delivery and metabolism of tirapazamine to tumour tissue using the multilayered cell culture model. Cancer Chemother. Pharmacol. 1999, 43, 213220.

(13) Hicks, K. O.; Pruijn, F. B.; Secomb, T. W.; Hay, M. P.; Hsu, R.; Brown, J. M.; Denny, W. A.; Dewhirst, M. W.; Wilson, W. R. Use of three-dimensional tissue cultures to model extravascular transport and predict in vivo activity of hypoxia-targeted anticancer drugs. J. Natl. Cancer Inst. 2006, 98, 1118-1128.

(14) Gandara, D. R.; Lara, P. N., Jr.; Goldberg, Z.; Le, Q. T.; Mack, P. C.; Lau, D. H.; Gumerlock, P. H. Tirapazamine: Prototype for a novel class of therapeutic agents targeting tumor hypoxia. Semin. Oncol. 2002, 29, 102-109.

(15) Lalani, A. S.; Alters, S. E.; Wong, A.; Albertella, M. R.; Cleland, J. L.; Henner, W. D. Selective tumor targeting by the hypoxia-activated prodrug AQ4N blocks tumor growth and metastasis in preclinical models of pancreatic cancer. Clin. Cancer Res. 2007, 13, 2216-2225.

(16) Patterson, A. V.; Ferry, D. M.; Edmunds, S. J.; Gu, Y.; Singleton, R. S.; Patel, K.; Pullen, S. M.; Hicks, K. O.; Syddall, S. P.; Atwell, G. J.; Yang, S.; Denny, W. A.; Wilson, W. R. Mechanism of action and preclinical antitumor activity of the novel hypoxia-activated DNA cross-linking agent PR-104. Clin. Cancer Res. 2007, 13, 3922-3932.

(17) Borch, R. F.; Liu, J.; Schmidt, J. P.; Marakovits, J. T.; Joswig, C.; Gipp, J. J.; Mulcahy, R. T. Synthesis and evaluation of nitroheterocyclic phosphoramidates as hypoxia-selective alkylating agents. J. Med. Chem. 2000, 43, 2258-2265.

(18) Borch, R. F.; Liu, J.; Joswig, C.; Baggs, R. B.; Dexter, D. L.; Mangold, G. L. Antitumor activity and toxicity of novel nitroheterocyclic phosphoramidates. J. Med. Chem. 2001, 44, 74-77.
(19) Colvin, O. M. An overview of cyclophosphamide development and clinical applications. Curr. Pharm. Des. 1999, 5, 555-560.

(20) Zhang, J.; Tian, Q.; Yung Chan, S.; Chuen Li, S.; Zhou, S.; Duan, W.; Zhu, Y. Z. Metabolism and transport of oxazaphosphorines and the clinical implications. Drug Metab. Rev. 2005, 37, 611-703.

(21) Bennewith, K. L.; Raleigh, J. A.; Durand, R. E. Orally administered Pimonidazole to label hypoxic tumor cells. Cancer Res. 2002, 62, $6827-6830$

(22) Evans, S. M.; Judy, K. D.; Dunphy, I.; Jenkins, W. T.; Nelson, P. T.; Collins, R.; Wileyto, E. P.; Jenkins, K.; Hahn, S. M.; Stevens, C. W.; Judkins, A. R.; Phillips, P.; Geoerger, B.; Koch, C. J. Comparative measurements of hypoxia in human brain tumors using needle electrodes and EF5 binding. Cancer Res. 2004, 64, 1886-1892.

(23) Rajendran, J. G.; Mankoff, D. A. Beyond detection: Novel applications for PET imaging to guide cancer therapy. J. Nucl. Med. 2007, 48, $855-856$.

(24) Hay, M. P.; Sykes, B. M.; Denny, W. A.; Wilson, W. R. A 2-nitroimidazole carbamate prodrug of 5-amimo-1-(chloromethyl)-3[(5,6,7-trimethoxyindol-2-yl)carbony 1]-1,2-dihydro-3H-benz[ $E]$ indole (amino-seco-CBI-TMI) for use with ADEPT and GDEPT. Bioorg. Med. Chem. Lett. 1999, 9, 2237-2242.

(25) Hay, M. P.; Wilson, W. R.; Denny, W. A. Nitroarylmethylcarbamate prodrugs of doxorubicin for use with nitroreductase gene-directed enzyme prodrug therapy. Bioorg. Med. Chem. 2005, 13, 4043-4055.

(26) Everett, S. A.; Naylor, M. A.; Patel, K. B.; Stratford, M. R.; Wardman, $\mathrm{P}$. Bioreductively-activated prodrugs for targeting hypoxic tissues: Elimination of aspirin from 2-nitroimidazole derivatives. Bioorg. Med. Chem. Lett. 1999, 9, 1267-1272.

(27) Fitzsimmons, S. A.; Workman, P.; Grever, M.; Paull, K.; Camalier, R.; Lewis, A. D. Reductase enzyme expression across the National Cancer Institute tumor cell line panel: Correlation with sensitivity to mitomycin C and EO9. J. Natl. Cancer Inst. 1996, 88, 259-269.

(28) Schlager, J. J.; Powis, G. Cytosolic NAD(P)H:(quinone-acceptor)oxidoreductase in human normal and tumor tissue: Effects of cigarette smoking and alcohol. Int. J. Cancer 1990, 45, 403-409.

(29) Rosen, L. S.; Laxa, B.; Boulos, L.; Wiggins, L.; Keck, J. G.; Jameson, A. J.; Parra, R.; Patel, K.; Brown, G. L. Phase 1 study of TLK286 (Telcyta) administered weekly in advanced malignancies. Clin. Cancer Res. 2004, 10, 3689-3698.

(30) Hay, M. P.; Anderson, R. F.; Ferry, D. M.; Wilson, W. R.; Denny, W. A. Synthesis and evaluation of nitroheterocyclic carbamate prodrugs for use with nitroreductase-mediated gene-directed enzyme prodrug therapy. J. Med. Chem. 2003, 46, 5533-5545.

(31) Rooseboom, M.; Commandeur, J. N. M.; Vermeulen, N. P. E. Enzymecatalyzed activation of anticancer prodrugs. Pharmacol. Rev. 2004, $56,53-102$

(32) Katz, M. H.; Takimoto, S.; Spivack, D.; Moossa, A. R.; Hoffman, R. M.; Bouvet, M. An imageable highly metastatic orthotopic red fluorescent protein model of pancreatic cancer. Clin. Exp. Metastasis 2004, 21, 7-12.

(33) Bouvet, M.; Spernyak, J.; Katz, M. H.; Mazurchuk, R. V.; Takimoto, S.; Bernacki, R.; Rustum, Y. M.; Moossa, A. R.; Hoffman, R. M. High correlation of whole-body red fluorescent protein imaging and magnetic resonance imaging on an orthotopic model of pancreatic cancer. Cancer Res. 2005, 65, 9829-9833.

(34) Hoffman, R. H. Orthotopic metastatic mouse models for anticancer drug discovery and evaluation: A bridge to the clinic. Invest. New Drugs 1999, 17, 343-359.

(35) Fu, X.; Guadagni, F.; Hoffman, R. M. A metastatic nude-mouse model of human pancreatic cancer constructed orthotopically from histologically intact patient specimens. Proc. Natl. Acad. Sci. U.S.A. 1992, 89, 5645-5649.

(36) Wardman, P. Electron transfer and oxidative stress as key factors in the design of drugs selectively active in hypoxia. Curr. Med. Chem. 2001, 8, 739-761.

(37) Wardman, P. The use of nitroaromatic compounds as hypoxic cell radiosensitizers. Curr. Top. Radiat. Res. Q. 1977, 11, 347-398.

(38) Paulson, O. B.; Melgaard, B.; Hansen, H. S.; Kamieniecka, Z.; Kohler, O.; Hansen, J. M.; Pedersen, A. G.; Tang, X.; Trojaborg, W. Misonidazole neuropathy. Acta Neurol. Scand. Suppl. 1984, 100, 133136.

(39) Naylor, M. A.; Threadgill, M. D.; Webb, P.; Stratford, I. J.; Stephens, M. A.; Fielden, E. M.; Adams, G. E. 2-Nitroimidazole dual-function bioreductive drugs: Studies on the effects of regioisomerism and sidechain structural modifications on differential cytotoxicity and radiosensitization by aziridinyl and oxiranyl derivatives. J. Med. Chem. 1992, 35, 3573-3578.

(40) Horwich, A.; Holliday, S. B.; Deacon, J. M.; Peckham, M. J. A toxicity and pharmacokinetic study in man of the hypoxic-cell radiosensitizer RSU-1069. Br. J. Radiol. 1986, 59, 1238-1240.

(41) Suto, M. J.; Stier, M. A.; Werbel, L. M. Dual-function radiosensitizers. $\alpha$-[[(2-Bromoethyl)amino]methyl]-2-nitro- $1 H$-imidazole-1-ethanol and 
related compounds: Preparation via an aziridine equivalent. J. Med. Chem. 1991, 34, 1207-1209.

(42) Overgaard, J. Clinical evaluation of nitroimidazoles as modifiers of hypoxia in solid tumors. Oncol. Res. 1994, 6, 509-518.

(43) Papadopoulou, M. V.; Bloomer, W. D. NLCQ-1 (NSC 709257): Exploiting hypoxia with a weak DNA-intercalating bioreductive drug. Clin. Cancer Res. 2003, 9, 5714-5720.

(44) Bolton, J. L; McClelland, R. A. Kinetics and mechanism of the decomposition in aqueous solutions of 2-(hydroxyamino)imidazoles. J. Am. Chem. Soc. 1989, 111, 8172-8181.
(45) Ludeman, S. M.; Boyd, V. L.; Regan, J. B.; Gallo, K. A.; Zon, G.; Ishii, K. Synthesis and antitumor activity of cyclophosphamide analogues. 4. Preparation, kinetic studies, and anticancer screening of "phenylketophosphamide" and similar compounds related to the cyclophosphamide metabolite aldophosphamide. J. Med. Chem. 1986, 29, 716-727.

(46) Struck, R. F.; Schmid, S. M.; Waud, W. R. Antitumor activity of halogen analogs of phosphoramide, isophosphoramide, and triphosphoramide mustards, the cytotoxic metabolites of cyclophosphamide, ifosfamide, and trofosfamide. Cancer Chemother. Pharmacol. 1994, 34, 191-196.

JM701028Q 